\title{
Implementation of Public Private Partnership in The Development of Tourism in Sumenep District
}

\author{
Arimurti Kriswibowo', Eka Arum Pramestya ${ }^{2}$, Khusnul Prasetyo ${ }^{3}$ \\ Ilmu Administrasi Negara, Fakultas Ilmu Sosial dan Ilmu Politik \\ Universitas Pembangunan Nasional "Veteran" Jawa Timur \\ Email: arimurti.adne@ upnjatim.ac.id ${ }^{1}$, ekaarumpra@gmail.com², \\ khusnulprasetyo4@gmail.com ${ }^{3}$
}

(Received: December 12-2019; revised: February 15-2020; published: June 31-2020)

\begin{abstract}
The development of the tourism sector in Sumenep City continues to be encouraged to improve the community's economy and increase Regional Original Revenue. But unfortunately the target of foreign tourist visits can not be achieved because of the availability of inadequate infrastructure. To meet these shortcomings, the Sumenep City Government established a partnership with PT. Persada Investama Karya Utama to establish a three-star hotel "de Baghraf". This study aims to describe the implementation of the Public Private Partnership (PPP) and describe in detail the benefits and the constraints faced in the construction of the three-star hotel "de Baghraf" in Sumenep conducted by the Government of Sumenep City with PT. Persada Investama Karya Utama. This research uses descriptive qualitative research methods using PPP theory. The results of this study indicate that the collaboration carried out using the Build Own Operate (BOO) partnership scheme is following the stipulated conditions because it has fulfilled the 9 (nine) stages of the implementation of Public Private Partnership. The benefits obtained from this Cooperation are supporting the implementation of Visit Sumenep and supporting tourism development programs, profits from hotel operations, and employment. Several obstacles were encountered such as low investor interest and difficulty in finding skilled human resources.
\end{abstract}

Keywords: Public Private Partnership; Build Own Operate (BOO); Tourism Development

\section{INTRODUCTION}

Indonesia is a special country, its natural beauty makes anyone amazed and amazed. This natural beauty will become a great potential if the government carries out sustainable national development (Niswaty et al., 2016). Sustainable national development is a series of sustainable development efforts, and encompasses all aspects of the life of the community, nation, and state intending to realize the national goals contained in the opening of the 1945 Constitution (Isnaini and Nawangsari, 2018). One form of sustainable management is the development tourism sector. The development of the tourism sector in Indonesia is very important to continue to be promoted. Through tourism, the potential of natural beauty is not just a mere visual display, but ideally should be able to improve the economy of the surrounding community, create community welfare and increase regional income through Regional Original Revenue (PAD). Therefore, each region needs to compete to develop the tourism sector by exploring the full potential of each region. 
214 Jurnal Ilmiah Ilmu Administrasi Publik: Jurnal Pemikiran dan Penelitian Administrasi Publik

Volume 10 Number 1, January - June 2020. Page 213-224

Based on (Undang-Undang Republik Indonesia Nomor 10 Tahun 2009 Tentang Kepariwisataan, 2009) explains that tourism is a variety of activities and is supported by various facilities and services provided by the community, entrepreneurs, government and local governments. While tourism is the whole activity related to tourism and is multidimensional and multidisciplinary which emerges as a manifestation of the needs of each person and country as well as interactions between tourists and the local community, fellow tourists, government, local governments, tourism entrepreneurs functioning to fulfill physical, spiritual and intellectual needs every tourist with recreation and travel as well as increasing state income to realize the welfare of the people.

In the development of tourism, many ways can be done. One of them is through the Public Private Partnership (KPS) program or what is known as Public Private Partnership (PPP). Public Private Partnership (PPP) is a series of relationships between public and private entities in infrastructure and other contexts (Said, Akib, et al., 2017; Said, Wahidiyat, et al., 2017). Other terms included in this type of cooperation are private sector participation and privatization (Felsinger, 2011). Meanwhile, according to Utama (2010) PPP is an ongoing linkage/synergy (long-term cooperation contract) in project development to improve public services (public services), including First, the government, or regional government as a regulator. Second, banks/consortia as funders, Third, Private parties / BUMN / BUMD as Special Purpose Company (SPC) are responsible for implementing a project starting from Design, Construction, Maintenance, and Operations.

The cooperation between the government and the private sector covers several things (Ikram, 2018), including 1) The private sector carries out some functions of the government for a certain time. 2) The private party receives compensation for the implementation of this function, both directly and indirectly. 3) The private party is responsible for risks arising from the implementation of this function. 4) Government facilities, land, or other assets can be submitted or used by private parties during the contract period. The three main needs that motivate governments to enter into PPPs for infrastructure are 1. to attract private capital investment (often to either supplement public resources or release them for other public needs); 2. to increase efficiency and use available resources more effectively; and 3. to reform sectors through a reallocation of roles, incentives, and accountability (Felsinger et al., 2008).

The things that cause the need for cooperation between the government and the private sector are among others the limited government funds, infrastructure which is inadequate both in terms of quantity and quality, expertise (technology) owned by the private sector (Utama, 2010). PPPs are a contemporary mechanism by which private sector businesses enter into contracts with governments to deliver public services that have traditionally been delivered by the state. PPPs are probably most commonly associated with infrastructure projects (Hellowell and Vecchi, 2015). Private enterprises provide the basic tourism products, facilities, and essential services, such as accommodation, transport, restaurants, retail, various attractions and even experiences Tonge and Myott (1996) quoted in (Lacy et al., 2002).

In the implementation of public private partnership there are several stages in the implementation of the agreement mentioned by Kementerian Koordinator Bidang Perekonomian Republik Indonesia (2010) in his book, which covers 9 (nine) stages: 1) Project Selection. The process aims to attract private partners and prioritize potential PPP infrastructure 
projects by taking into account government policies, resources, and readiness of the projects to be undertaken. 2) Public Consultation. Efforts are used to obtain advice from the public, investors, and lenders as needed regarding the design of a particular project. 3) Feasibility Study. The feasibility study is carried out to meet the stages that exist in public and private collaboration, a feasibility study will be conducted by the government that must be completed before the project is tendered. 4) Risk Review. Stage to identify various risks in the project and things that can reduce the risk of a project to be implemented and the proposed risk transfer. 5) Form of Cooperation. Cooperation between private governments can be applied in various forms of agreements including BOT (Build, Operate, Transfer), BOO (Build, Own, Operate), BROT (Build, Rent, Operate, Transfer), KSO (Joint Operation / Joint Operation), and joint ventures. 6) Government Support. Government support aims to find out the potential financial wealth in a project. 7) Procurement. The tender procurement process is carried out in the stages of project preparation, pre-qualification of tender and evaluation, negotiation to contract signing. 8) Implementation. Project implementation is carried out when a project is signed until the end of the project, including the establishment of a Project Company by the Project Sponsor, financing, construction activities, initial implementation, and operation of the project by the business entity. 9) Supervision. The purpose of project monitoring Cooperation between the Government and the private sector is to ensure that project operations are following regulations and ensure that work agreements are following the results of implementation.

Sumenep Regency in Madura Songennep is one of the districts located at the eastern end of Madura Island, East Java. The geographical condition of the region is between the islands which have around 126 islands. The natural tourism object is so beautiful, especially Lombang Beach with its evergreen pine forest and Slopeng Beach with its white dunes look so enchanting. Another potential of the Sumenep archipelago is equally as Mamburit Island, Sapudi Island, Kangean Island, and Raas Island where the sea view is decorated with beautiful coral and sparkling white sand.

Seeing the beautiful natural and cultural potential, one of the efforts made by the Government of Sumenep Regency, Madura, East Java in developing the tourism sector is to hold an annual event that is expected to attract tourist visits. The event is "Visit Sumenep" which has been launched since 2017 and has been realized by the Sumenep Regency Government in 2018. This annual event is consistently run until 2019 to introduce Sumenep as a tourism city through various activities. There are at least 36 events or festivals prepared to welcome Visit Sumenep.

Some evaluations and records of the implementation of Visit Sumenep 2018 and 2019 are targets of foreign tourist visits targeted at around 5,000 people, in fact, unable to be achieved. Data from the Department of Tourism of Youth Culture and Sports (Disparbudpora) Sumenep written by Bongkar 86.com (2018) stated that the achievement of visits only reached 70 percent of the targeted tourist visits. While the target for local tourist visits has been reached around 1.2 million more. The target of foreign tourist visits that cannot be achieved is judged to be caused by several factors namely inadequate infrastructure and facilities. According to Anita dan Supriono (2018) Other supporting things needed to develop tourism potential are the availability of facilities, infrastructure, and infrastructure supported by the role of stakeholders in developing tourism. 
216 Jurnal Ilmiah Ilmu Administrasi Publik: Jurnal Pemikiran dan Penelitian Administrasi Publik Volume 10 Number 1, January - June 2020. Page 213-224

To support this, Sumenep Regency needs a minimum of three-star class hotels, not jasmine class to attract tourists and make tourists feel comfortable visiting Sumenep Regency. During this time the construction of jasmine hotels are allowed to mushroom, it is undeniable that the economic development in the easternmost district of Madura Island is still stagnant. Based on the results of the evaluation, the Sumenep Regency Government tried to establish cooperation with PT. Persada Investama Karya Utama to establish a three-star hotel that was initiated since 2018 and hotel construction began in 2019. Until finally, at the end of 2019 the first three-star hotel in Sumenep named "de Baghraf" was officially opened.

It is interesting to study, therefore, this is what then underlies the author to research to find out and describe the implementation of Public Private Partnership (PPP) and describe in detail the benefits and the constraints faced in the construction of three-star hotel "de Baghraf" in Sumenep conducted by the Government of Sumenep Regency with PT. Persada Investama Karya Utama.

\section{METHOD}

This research was conducted with data collection techniques through interviews, observations, and literature review with searches obtained from previous research, news, and data from the Central Statistics Agency (BPS), as well as other article sources that can support this research. The type of research used is qualitative. Qualitative research is descriptive and tends to use inductive analysis. Researchers depart from the data, and utilize existing theories as explanatory material, then end up on a hypothesis or theory (Hadi, 2017).

Descriptive research is not too prioritizing meaning, on the contrary, the emphasis is on descriptive analyzing more data surfaces, only paying attention to the processes of occurrence of a phenomenon, not the depth of data or the meaning of data (Umami, 2015). The qualitative method is used because it has characteristics following the research topic. This research departs from social problems, problems that exist in society, and develops every time.

The data analysis technique that will be used in this study is the Interactive model from Miles and Huberman (Sugiyono, 2018). Data analysis techniques are divided into 4 (four stages) viz. First, data collection using interview techniques, field observations, and literature studies concerning data triangulation techniques. Second, data reduction by summarizing the results of research. Third, the presentation of data in the form of a description. Fourth, drawing conclusions and verification.

\section{RESULT AND DISCUSSION}

\section{Public Private Partnership (PPP) Implementation}

The process of implementing cooperation between the Sumenep Regency Government and PT. Persada Investama Karya Utama can be seen through 9 (nine) stages of the implementation of Public Private Partnership (KPS), including: 


\section{Project selection}

The Sumenep Regency Government from the start did need the support of the private sector and investors who were interested in establishing a five-star hotel. Sumenep Regent, Abuya Busyro Karim explained that Sumenep Regency needed more five-star hotels along with the local government's program that wanted to make Sumenep a tourist city. Starred hotels are not a matter of lifestyle, nor is it a necessity. But it is a real need in answering the challenges of the increasing number of tourists to Sumenep. On the other hand, with the existence of a five-star hotel, it hopes to support the annual tourism event, Visit Sumenep. So far, Sumenep has often failed to hold national and international events due to a lack of hotels. To accelerate the process of building a three-star hotel, the Sumenep Regency Government has cooperated in a Public Private Partnership (PPP) partnership with the private sector, PT. Persada Investama Karya Utama which is a national private company domiciled at Jalan Raya Panglima Besar Sudirman Number 5-5A, Pajagalan Kelurahan, Sumenep City District, Sumenep Regency. This is possible with several underlying legal frameworks, including the use of the Government and Business Entity Cooperation system outlined in Peraturan Presiden Republik Indonesia Nomor 38 Tahun 2015 Tentang Kerjasama Pemerintah Dengan Badan Usaha Dalam Penyediaan Infrastruktur In this collaboration, PT. Persada Investama Karya Utama has followed all applicable provisions and procedures, one of which is the submission of proposals and application letters. In licensing the construction of the de Baghraf hotel in Sumenep, the Sumenep Regency Government finally issued an Approval Letter on the Results of the Coordination Meeting and Site Review of the Integrated OneStop Licensing Services Technical Team Number: 503.1 / 239 / 435.120 .4 / 2019 regarding Application for Establishing a "DE - Starred Hotel" BAGHRAF SUMENEP "located on Jl. Raya Panglima Besar Sudirman Number 5-5A, Pajagalan Kelurahan, Sumenep City Subdistrict, Sumenep Regency. The letter was issued based on the Application Letter of Brother Hilmy Gauzan, Director of PT. Persada Investama Karya Utama on February 15, 2019 with the Business Registration Number 9120005251452.

\section{Public Consultation}

Before entering the stage of the construction of a three-star hotel, the Sumenep Regency Government conducted several mediations to an internal consultant who was appointed directly by the Sumenep Regency Government. Internal consultants here have not been explained in full and comprehensively related to the person in question. Besides, the Sumenep Regency Government also consulted the Sumenep Regency DPRD to obtain suggestions, input, and considerations regarding prospects and the impacts that can be felt by the community.

\section{Feasibility Study}

The Sumenep Regency Government formed the One-Stop Integrated Licensing Technical Technical Team to review proposals and application letters submitted by PT. Persada Investama Karya Utama by taking into account the procedures that have been determined. 
218 | Jurnal Ilmiah Ilmu Administrasi Publik: Jurnal Pemikiran dan Penelitian Administrasi Publik

Volume 1o Number 1, January - June 2020. Page 213-224

Based on the results of the coordination meeting which was followed by a site review with the Sumenep Regency One-Stop Integrated Licensing Technical Team on March 21, 2019, the request of brother Hilmy Gauzan, Director of PT. Persada Investama Karya Utama, in principle, the Technical Team does not object if it is continued by fulfilling the following commitments: completing the Environmental Management Efforts (UKL) document and Environmental Monitoring Efforts (UPL) whose material is adjusted to the business plan and / or activity at the recommended business location by the Sumenep Regency Environmental Agency, provided that PT. Persada Investama Karya Utama must be willing not to pollute the environment around the location of the business location, provide Light Fire Extinguishers (APAR) to anticipate/prevent the occurrence of fire hazards and make a septic tank specifically for liquid waste in the bathroom.

Apart from that, based on Peraturan Menteri Dalam Negeri Republik Indonesia Nomor 32 Tahun 2010 Tentang Pedoman Pemberian Izin Mendirikan Bangunan and as with the building construction prerequisites that must be following the technical provisions and the Spatial Planning Technical Recommendations of the Department of Public Housing, Settlement Areas and Cipta Karya of Sumenep Regency on the Regency Spatial Planning. Besides, it is also necessary to pay attention to the Road Border Line (GSJ) 8 meters from the axle to the fence and 13 meters from the axle to the hotel building, for the access road from the road to the building must be at the level of the road shoulder (may not exceed the shoulder).

4. Risk Review

Is a stage carried out in conjunction with a feasibility study, Sumenep Regency Government sees the magnitude of deviations between the expected rate of return in the future such as the possibility of loss, uncertainty, the probability of deviation from the expected results. The Government of Sumenep Regency views optimistically that three-star hotel development projects can succeed as expected and will truly benefit both from the government and private sides because the hotel becomes a basic requirement of sustainable tourism governance. Besides, the risk review also sees the possibility of a violation of private commitments from the provisions set by the government. Therefore the Sumenep Regency Government is trying to optimize the role of the One-Stop Integrated Licensing Services Technical Team to conduct intensive supervision in the hotel construction process.

\section{Form of Cooperation}

The form of Public Private Partnership (PPP) partnership in the construction of three-star hotels in Sumenep Regency is in the form of Build, Own, Operate (BOO). BOO is a form of cooperation in the PPP where the private sector builds, the private sector owns the facility and operates it (Utama, 2010). In other words, the government relinquishes its rights and responsibilities for a public infrastructure to the private sector to finance, build, own, and operate a new infrastructure forever. In this case the private sector or investors, namely PT. Persada Investama Karya Utama, which builds and operates facilities without having to return ownership to the government. Some examples of BOO are the construction of airports, toll roads, hotels, ports, water supply and distribution, hospitals, and sports facilities. 
6. Government Support.

The Sumenep Regency Government provides full support to PT. Persada Investama Karya Utama in the establishment of the de Baghraf hotel by providing facilities in obtaining permits for Building Construction Permits (IMB). The government also helps in meeting the needs of facilities such as the installation of PDAM water channels that originate from Lake Lake 'water sources in Sumenep City District through the Regional Water Supply Company (PDAM) Tirta Dharma Sumekar, Sumenep Regency. Also, the Government of Sumenep Regency has always monitored and monitored directly during the construction process and until now the de Baghraf hotel has been operated. The Government should support cooperation with the private sector in activities related to improving public services, because PPP allows the public sector to get better value for money in the delivery of public services. Moreover, by switching its role from a provider to a buyer of services, the Government can focus on its core responsibilities of policy-making and regulation ((Ministry of Finance Singapore, 2012)

\section{Procurement}

Collaboration between the Sumenep Regency Government and PT. Persada Investama Karya Utama uses a solicited system which is an infrastructure project initiated by the government and offered to business entities (private) for cooperation. After getting an evaluation from the Sumenep Regency DPRD, the Sumenep Regency Government immediately prepared everything needed so that Sumenep Regency would soon have a three-star hotel, mainly investors who were able to fulfill the government's wishes. The Sumenep Regency Government is very grateful that PT. Persada Investama Karya Utama is an investor who is willing to undertake the construction of a three-star hotel in Sumenep Regency with an investment of up to Rp. 5 billion rupiahs with a land area of 1,682 square meters.

8. Implementation

In the implementation of construction which includes a series of planning and implementation activities along with supervision covering architectural, civil, mechanical, electrical, and environmental management as well as financing to realize the building or physical form of the de Baghraf hotel is fully carried out by PT. Persada Investama Karya Utama. The private sector is given full authority over the operation of the hotel by the Sumenep Regency Government. The construction was carried out for ten (10) months from February 2019 to December 2019. It was inaugurated by the Deputy Regent of Sumenep, Achmad Fauzi on Wednesday, December 25, 2019, followed by officials of the Sumenep Regency Forkopimda and invited hundreds of orphans. In his remarks, Achmad Fauzi said, de Baghraf hotel became the 16th hotel operating in Sumenep Regency, and being the only three-star hotel, Hotel de Baghraf was expected to be an option for tourists visiting Sumenep.

9. Supervision

Oversight of Public Private Partnership (PPP) collaboration between the Sumenep Regency Government and PT. Persada Investama Utama Karya is carried out by many Regional Apparatus Organizations (OPD) within the Sumenep Regency government environment 
220 Jurnal Ilmiah Ilmu Administrasi Publik: Jurnal Pemikiran dan Penelitian Administrasi Publik Volume 10 Number 1, January - June 2020. Page 213-224

including the Investment and One-Stop Integrated Services Office by forming a One-Stop Integrated Licensing Technical Team, the collaboration also coordinates with the Revenue, Financial Management, and Regional Assets Agency Sumenep Regency. Besides, the Commission C of the Sumenep Regency DPRD in charge of the field of development with the assignment of assignments includes public works, spatial development planning and regional urban planning in the context of the construction of three-star hotels taking on the role of overseeing the compatibility of agreements with reality on the ground. Sumenep Regency DPRD conducts supervision by requesting reports on the progress of project development from the Sumenep Regency Government through joint meetings between the legislature and the executive. The Sumenep Regency Government together with the Sumenep Regency DPRD can also conduct spot checks on the ground if there are irregularities or project misappropriations by inviting PT. Persada Investama Karya Utama. However, so far there have not been any problems created by the private sector or the Sumenep Regency Government in the construction of the de Baghraf three-star hotel project in Sumenep Regency.

\section{Benefits and Constraints Of Cooperation Between Sumenep District Government with PT. Persada Investama Karya Utama}

\section{Benefits of Cooperation between the Sumenep Regency Government and PT. Persada Investama Karya Utama}

The benefit obtained by the Sumenep Regency Government with the existence of a threestar de Baghraf hotel is to help the success of the government's work program in supporting the Visit Sumenep which is held every year to boost the tourism sector. Going forward, the de Baghraf hotel is also expected to be able to contribute to the Regional Original Revenue (PAD) of Sumenep Regency. The benefits that can be felt directly by the people of Sumenep from the construction of a three-star de Baghraf hotel are reducing unemployment and absorbing the workforce to hundreds of people both during the construction process until the de Baghraf hotel operates. At the very least, de Baghraf hotel needs construction workers, administrative staff, security officers, cooks, janitors, parking attendants, hotel maids, and other duty needs.

The private sector, in this case, PT. Persada Investama Karya Utama also received great benefits in the form of profits or profits since the hotel de Baghraf has been operating because it has a characteristic that is the only three-star hotel in Sumenep Regency so that it is the main target of tourists who come from various places to stay. In some tourism events organized by the Government of Sumenep Regency in the future, the de Baghraf hotel will be prepared to accommodate foreign tourists who come from various parts of the world to see the natural beauty of the land and islands in Sumenep Regency.

\section{Constraints on Cooperation between the Government of Sumenep Regency and PT. Persada Investama Karya Utama}

In the beginning, the Sumenep Regency Government experienced obstacles to building a three-star hotel, because of the previous experience of several infrastructure development 
projects such as bridges, roads, and sidewalks that were devoted to enthusiasts, investors tended to hesitate to invest in Sumenep Regency. Also, in terms of budget, the Sumenep Regency Government has limitations, based on the 2019 Sumenep Regency Regional Revenue and Expenditure Budget Appendix Document shows a dependency on Balancing Funds such as TaxSharing Funds / Non-Tax Profit Sharing Funds, General Allocation Funds (DAU) and The Special Allocation Fund (DAK) reached 1.7 trillion, compared to the Regional Original Revenue (PAD) obtained by the Sumenep Regency which was only 254.5 billion. The budget must still be divided into several other sectors such as health, education, social and public services.

PT. Persada Investama Karya Utama as a private party at first had hesitated to build a three-star de Baghraf hotel in Sumenep Regency because they were worried about the complicated licensing process for hotel construction, strict conditions, and procedures that had to be met through a project feasibility study until the government guarantee was unclear. In infrastructure development projects, government guarantees are very important. Because investment in the sector requires a long term and a large investment cost so it is vulnerable to changes in government policy. However, PT. Persada Investama Karya Utama then solidified its conviction to be willing to build a three-star hotel because the Government of Sumenep Regency tried to convince by ensuring that it would fully support the construction of a three-star hotel and facilitate all the processes of licensing the establishment of hotels due to the insistence on the needs of the tourism industry. Of course the implementation must be following the provisions of the legislation in force.

PT. Persada Investama Karya Utama also has difficulty finding Human Resources (HR) who have special expertise to be involved in the hotel construction process. The lack of skilled human resources in Sumenep Regency has resulted in the private sector only taking local native workers to be employed at the work level that relies on labor. Meanwhile, to meet the needs of skilled workers, PT. Persada Investama Karya Utama took workers from outside the Sumenep Regency area.

\section{CONCLUSION}

Based on the guidelines regarding the procedures for Public Private Partnership (KPS) established by the Coordinating Ministry for the Economy, the implementation of the Public Private Partnership (PPP) between the Sumenep Regency Government and PT. Persada Investama Karya Utama has fulfilled the stipulated provisions, because in the cooperation it fulfills 9 (nine) stages of the implementation of Public Private Partnership (KPS), although there are still shortcomings in its implementation. Seen from the implementation stage the cooperation agreement was established using the Build, Own, Operate (BOO) scheme between the Sumenep Regency Government and PT. Persada Investama Karya Utama. The implementation of the Public Private Partnership (PPP) model in the construction of the first three-star hotel project in Sumenep certainly brings benefits to the government, which can increase revenues in the tourism sector, the results of which can also be felt by the community. The private sector will also benefit financially as long as the hotel operates. 
222 Jurnal Ilmiah Ilmu Administrasi Publik: Jurnal Pemikiran dan Penelitian Administrasi Publik Volume 10 Number 1, January - June 2020. Page 213-224

\section{REFERENCES}

Anita, D. M. D., \& Supriono. (2018). Analisis Partisipasi Masyarakat Lokal Dalam Pengembangan Pariwisata Di Pulau Gili Labak Kabupaten Sumenep. Jurnal Administrasi Bisnis (JAB), 61(4), 29-38.

Bongkar 86. (2018). Hasil Evaluasi Visit 2018: Kunjungan Wisatawan Manca Negara Tak Sesuai Target, Sumenep Butuh Hotel Berbintang. Bongkar 86.com.

Felsinger, K. (2011). Public-Private Partnership Handbook. World Bank.

Felsinger, K., Miranda, J., \& Skilling, H. (2008). Public-Private Partnership Handbook. Asian Development Bank.

Hadi, S. (2017). Pemeriksaan Keabsahan Data Penelitian Kualitatif pada Skripsi. Jurnal Ilmu Pendidikan, 22(No. 1), 1-6.

Hellowell, M., \& Vecchi, V. (2015). The Non-Incremental Road to Distate? A Comparative Policy Analysis of Agency Problems in the UK and Italy. Journal of Comparative Policy Analysis, 17(5), 519-532.

Ikram, M. (2018). Public Private Partnership Dalam Pengembangan Potensi Wisata di Kabupaten Kuantan Singingi Tahun 2011-2015. Jurnal Online Mahasiswa Fakultas Ilmu Sosial Dan Ilmu Politik (JOM FISIP), 5(1), 1-8.

Isnaini, A. J., \& Nawangsari, E. R. (2018). Peran Badan Usaha Milik Desa (BUMDES) "Usaha Mandiri Sejahtera" Dalam Pengelolaan Himpunan Penduduk Pemakai Air Minum (HIPPAM) Di Desa Kesamben Wetan Kecamatan Driyorejo Kabupaten Gresik. Jurnal Dinamika Governance, 8(2), 156-164.

Kementerian Koordinator Bidang Perekonomian Republik Indonesia. (2010). Kerjasama Pemerintah dan Swasta ( KPS ) Panduan Bagi Investor Dalam Investasi. Kementerian Koordinator Bidang Perekonomian.

Lacy, T., De, B. M., Moore, S., \& Noakes, S. (2002). Public Private Partnership For Sustainable Tourism Delivering A Sustainability Strategy for Tourism Destinations July 2002 Asia Pacific Economic Cooperation. APEC Secretariat.

Ministry of Finance Singapore. (2012). Public Private Partnership Handbook (II). Ministry of Finance, Singapore.

Niswaty, R., Darwis, M., Alimuddin, W., \& Salam, R. (2016). Pengaruh Penerapan Prinsip Good Governance terhadap Efektivitas Kerja Pegawai. Jurnal Ilmiah Administrasi Publik (JIAP), 95-100.

Peraturan Menteri Dalam Negeri Republik Indonesia Nomor 32 Tahun 2010 Tentang Pedoman Pemberian Izin Mendirikan Bangunan, (2010).

Peraturan Presiden Republik Indonesia Nomor 38 Tahun 2015 Tentang Kerjasama Pemerintah Dengan Badan Usaha Dalam Penyediaan Infrastruktur, (2015).

Said, F., Akib, H., Salam, R., \& Baharuddin, A. (2017). An Analysis of Tourism Visit Trend. 2nd International Conference on Education, Science, and Technology (ICEST 2017).

Said, F., Wahidiyat, A., Andayani, D. D., Harifuddin, H., \& Salam, R. (2017). Development of Travel Attractions Through the Design of Google SketchUp Based Coastal Tourist Map (Pengembangan Daya Tarik Wisata Melalui Perancangan Peta Wisata Pantai Berbasis Google SketchUp). Pekommas, 2(2). 
Sugiyono. (2018). Metode Penelitian Kuantitatif, Kualitatif dan R\&D. Alfabeta.

Umami, Z. (2015). Social Strategy Pada Media Sosial Untuk Promosi Pariwisata Daerah Istimewa Yogyakarta. Interaksi: Jurnal Ilmu Komunikasi, 4(2), 195-201. https://doi.org/10.14710/interaksi,4,2,195-201

Undang-Undang Republik Indonesia Nomor 10 Tahun 2009 Tentang Kepariwisataan, Pub. L. No. 10 (2009).

Utama, D. (2010). Prinsip dan Strategi Penerapan "Public Private Partnership" Dalam Penyediaan Infrastruktur Transportasi. Jurnal Sains Dan Teknologi Indonesia, 12(3), $145-151$. 
224 Jurnal Ilmiah Ilmu Administrasi Publik: Jurnal Pemikiran dan Penelitian Administrasi Publik Volume 10 Number 1, January - June 2020. Page 213-224 